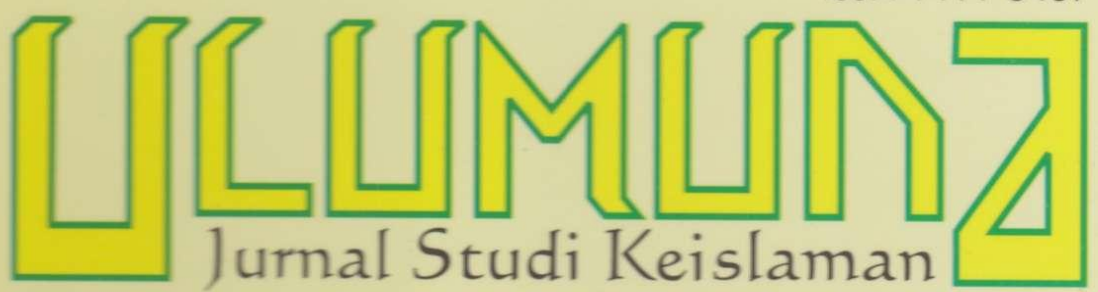

Volume 16 • Nomor 2• Desember 2012

Terakreditası B; SK Dirjen Dikti Kemdikbud Nomor: 56/DIKTI/Kep/2012, Tanggal 24 Juli 2012

REORIENTASI KAJIAN TEOLOGI ISLAM: IKHTIAR KONTRIBUTIF ATASI PROBLEM KEKINIAN Muhammad Rusli

PERGOLAKAN TEOLOGI SYIAH-SUNNI: MEMBEDAH POTENSI INTEGRASI DAN DISINTEGRASI

Slamet Mulyono MEnimbang KontorVERSI PEMAKNAAN KONSEP AHL AL-KITĀB DALAM AL-QUR'AN Zulyadain ECOTHEOLOGY:

TEOLOGI KONSTRUKTIF ATASI KRISIS LINGKUNGAN Abdul Quddus AKU DALAM TUHAN: IMPLIKASI TEOLOGI PROSES PADA ERA KONTEMPORER Suhermanto la'far PERgulatan TEOLOGI SALAFI DALAM MAINSTREAM KEBERAGAMAAN MASYARAKAT SASAK Faizah STUDI KOMPARATIF KONSEP KETUHANAN ISLAM DAN AGAMA ADAM PADA KOMUNITAS SAMIN Mohammad Rosyid KEGALAUAN IDENTITAS:

Dilema Hubungan Komunitas Muslim dan Hindu di BalI Siti Raudhatul Jannah 



\section{DAFTAR ISI}

\section{Pedoman Transliterasi}

\section{3-244 • Muhammad Rusli,}

"Reorientasi Kajian Teologi Islam:

Ikhtiar Kontributif Atasi Problem Kekinian"

245-278 • Slamet Mulyono,

"Pergolakan Teologi Syiah-Sunni:

Membedah Potensi Integrasi dan Disintegrasi"

279-310 • Zulyadain,

"Menimbang Kontorversi Pemaknaan

Konsep Ahl Al-Kitāb Dalam Al-Qur'an"

311-346 • Abdul Quddus,

"Ecotheology:

Teologi Konstruktif Atasi Krisis Lingkungan"

347-374 • Suhermanto Ja'far,

"Aku dalam Tuhan:

Implikasi Teologi Proses pada Era Kontemporer”

375-402 • Faizah,

"Pergulatan Teologi Salafi

dalam Mainstream Keberagamaan Masyarakat Sasak"

403-442 • Mohammad Rosyid,

"Studi Komparatif Konsep Ketuhanan Islam

dan Agama Adam pada Komunitas Samin"

443-464 • Siti Raudhatul Jannah,

"Kegalauan Identitas: Dilema Hubungan

Komunitas Muslim dan Hindu di Bali”

\section{INDEKS}

APENDIKS 


\section{PEDOMAN TRANSLITERASI}

\begin{tabular}{|c|c|c|c|c|c|c|}
\hline 1 & $=$ & $\mathbf{a}$ & & $\dot{\varepsilon}$ & $=$ & $\mathrm{g}$ \\
\hline ب & $=$ & b & & ف & $=$ & f \\
\hline$ت$ & $=$ & $\mathbf{t}$ & & ق & $=$ & $q$ \\
\hline$\dot{H}$ & $=$ & th & & ك & $=$ & $\mathbf{k}$ \\
\hline ج & $=$ & $\mathbf{j}$ & & J & $=$ & 1 \\
\hline$\tau$ & $=$ & ḥ & & s & $=$ & $\mathrm{m}$ \\
\hline$\dot{\tau}$ & $=$ & $\mathbf{k h}$ & & $\dot{ن}$ & $=$ & $\mathbf{n}$ \\
\hline$د$ & $=$ & d & & 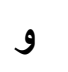 & $=$ & $\mathbf{w}$ \\
\hline$\dot{j}$ & $=$ & dh & & ○ & $=$ & $\mathbf{h}$ \\
\hline$\jmath$ & $=$ & $\mathbf{r}$ & & $\varepsilon$ & $=$ & , \\
\hline j & $=$ & $\mathbf{z}$ & & ي & $=$ & $\mathbf{y}$ \\
\hline س س & $=$ & s & & & & \\
\hline 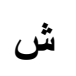 & $=$ & sh & \multicolumn{4}{|c|}{ Untuk Madd dan Diftong } \\
\hline ص - ص & $=$ & ș & i & $=$ & \multicolumn{2}{|c|}{$\bar{a}$ (a panjang) } \\
\hline ض ض & $=$ & d & إي & $=$ & \multicolumn{2}{|c|}{$\overline{1}$ (i panjang) } \\
\hline b & $=$ & $t$ & أو & $=$ & \multicolumn{2}{|c|}{ ù (u panjang) } \\
\hline ظ & $=$ & z & او & $=$ & \multicolumn{2}{|c|}{ aw } \\
\hline$\varepsilon$ & $=$ & ' & أي & $=$ & \multicolumn{2}{|l|}{ ay } \\
\hline
\end{tabular}

Contoh penulisan dengan transliterasi:

اعوذ بالله من الشيطان الرجيم (a'üdhu bi al-Lāh min al-shaytān al-rajīm);

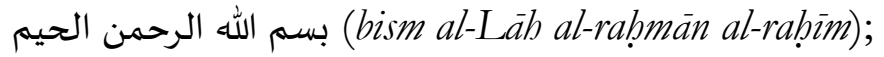

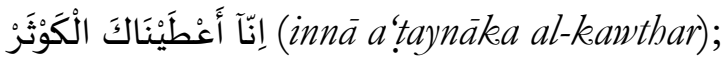

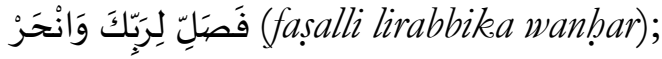

صباح الخير (sabāh al-khayr). 


\title{
REORIENTASI KAJIAN TEOLOGI ISLAM: IKHTIAR KONTRIBUTIF ATASI PROBLEM KEKINIAN
}

\author{
Muhammad Rusli \\ (Fakultas Ushuluddin dan Dakwah IAIN Sultan Amai Gorontalo. \\ Email:muhammadruslii@yahoo.com
}

Abstract: The central issue in the study of classical Islamic theologians is closely linked with their surrounding context challenging them at the time. One of the basic problems is the incessant spread of Greek philosophy and elements of non Islamic teachings involved in the struggle of Islamic thought at the time, so that the theologians found it corrupting the Islamic faith. The study of Islamic theology at the time, therefore, was aimed at anticipating the destruction of Islamic values. Philosophical values of the movement should inspire contemporary theologians to resolve the various problems faced by the muslim communities. Therefore, contemporary study of Islamic theology should not divell on the issues of "heavens" and be busy of "defending the God". It should go further into the solution to the problem of the muslim people and human in general today.

Abstrak: Isu sentral yang menjadi kajian para teolog Islam Klasik sangat erat kaitannya dengan konteks tantangan zaman yang melingkupinya. Salab satu persoalan mendasar saat itu adalah gencarnya penyebaran filsafat Yunani dan unsur-unsur ajaran luar Islam yang terlibat dalam pergumulan pemikiran keislaman, sehingga memunculkan kekhawatiran akan rusaknya akidah Islam. Untuk itu, kajian teologi Islam diarabkan untuk mengantisipasi hal tersebut. Nilai filosofis dari gerakan ini seharusnya menginspirasi para teolog kekinian untuk dapat menyelesaik.an berbagai macam persoalan umat yang muncul. Teologi Islam tidak seharusnya berkutat pada persoalan "langit" dan sibuk "membela Tuhan", tetapi ia mesti beranjak lebih jauh untuk menjadi solusi bagi persoalan umat Islam dan manusia pada umumnya saat ini.

Keywords: reorientasi, kontekstualisasi, teologi Islam, problem kekinian, teologi klasik, teologi kontemporer. 
SEIRING perkembangan zaman, minat berbagai kalangan untuk mengkaji teologi Islam mulai redup, karena dianggap tidak relevan dalam menyelesaikan problem dunia kekinian. Hal tersebut ada benarnya, bilamana teologi Islam hanya dipahami sebagai bentuk nostalgia terhadap pemikiran klasik Islam. Teologi Islam hanya dipelajari secara dogmatis, tanpa sikap kritis, dan hanya diposisikan sebagai kekayaan intelektual para pemikir Islam klasik yang disucikan. Namun menjadi lain, ketika ilmu ini dikaji dan dikembangkan secara komprehensif serta dihubungkan dengan persoalan-persoalan kekinian sebagai salah satu alternatif solusi.

Teologi Islam seharusnya tidak berkutat pada persoalanpersoalan "langit", tetapi harus menjadi pelopor dari gerakan pembaharuan. Jika melirik dari sejarahnya, menurut Zurkani Jahja, teologi Islam merupakan wujud respons terhadap gencarnya penyebaran filsafat Yunani dan unsur-unsur ajaran luar Islam yang ikut terlibat dalam pergumulan pemikiran keislaman saat itu. Ideologi dan pemikiran-pemikiran filosofis itu sedemikian luas penyebarannya, sehingga ulama merasa perlu untuk mengantisipasi kemungkinan tercemarnya akidah umat Islam. Mereka lalu menulis karya-karya yang berisi antara lain argumen-argumen yang diharapkan dapat menjadi benteng bagi akidah umat Islam dengan dalil-dalil yang ditawarkan tidak lagi hanya berkutat pada dalil-dalil naqli tetapi sudah mulai banyak melibatkan logika-logika rasional. ${ }^{1}$

Jika pada masa lalu teologi Islam diperhadapkan pada gencarnya penyebaran filsafat Yunani, maka sekarang teologi Islam diharapkan mampu mengikuti mainstream pemikiran kontemporer. Pemikiran Islam mesti bergumul dengan pemikiran filsafat Barat kontemporer, problem-problem sosialpolitik, pendidikan, iptek, dan lain sebagainya. Hal ini tidak lain agar teologi Islam tidak melulu melekat pada upaya apologetik "membela Tuhan". Para pemikir harus mengembalikan elan vital untuk menjawab tantangan zaman yang melingkupinya. Tantangan yang muncul sekarang sudah sama sekali berbeda. Tantangan-tantangan baru masih akan terus bermunculan, sesuai

1Zurkani Jahja, Teologi al-Ghazali -Pendekatan Metodologi (Yogyakarta: Pustaka Pelajar, 1996), 81. 
dengan perkembangan ilmu pengetahuan modern. Termasuk isu-isu kemanusian universal, pluralisme keagamaan, kemiskinan struktural, kerusakan lingkungan hidup adalah di antara persoalan kontemporer yang perlu mendapat perhatian serius dalam konteks teologis. ${ }^{2}$ Isu yang lain yakni munculnya gerakan anti Islam dengan berbagai macam bentuknya baik dalam bentuk karikatur Nabi, film anti Islam (Innocence of Muslims), buku atau majalah anti Islam dan semacamnya. Isu yang tak kalah pentingnya adalah korupsi berjamaah di kalangan pejabat negara, merebaknya faham keagamaan baru di Indonesia, dan lain sebagainya.

Kehadiran tulisan ini diharapkan mampu memberikan penjelasan mendasar tentang pentingnya reorientasi kajian teologi Islam yang tidak hanya berkutat tentang Tuhan, rasul dan hal-hal yang terkait dengannya disebabkan kondisi atau tuntutan zaman pada waku itu. Sudah waktunya para pemikir Islam mengembangkan atau reorientasi kajian teologi Islam sebagai jawaban atas problem kekinian.

\section{Dasar dan Arah Reorientasi Kajian Teologi Islam}

Reorientasi tentunya akan menuai sejumlah pertanyaan, di antaranya; Apakah memungkinkan reorientasi kajian teologi Islam dilakukan?, apakah reorientasi tersebut tidak mereduksi atau menyimpang dari bangunan teologi Islam yang telah mapan di kalangan umat Islam?, mampukah reorientasi memberikan solusi bagi problem umat kekinian?, dan berbagai pertanyaan yang mungkin muncul seputar gagasan tersebut.

Hasan Hanafi salah seorang intelektual Muslim menyadari adanya perbedaan orientasi teologi Islam masa Klasik dan Kontemporer, sehingga beliau mengajukan konsep teologi Islam yang ia namakan Ilmu Usuluddin sebagai ilmu yang membaca dalam akidah atau dogma Islamiyah kenyatan kaum Muslimin yang berupa penjajahan, keterbelakangan, ketertindasan, kemiskinan, keterasingan, keterpecahbelahan, dan ketidakpeduliaan. Ilmu itu juga membaca dalam akidah itu sendiri tentang kebebasan, unsur-unsur kemajuan dan syarat-syarat

${ }^{2}$ Amin Abdulllah, Falsafah Teologi Islam di Era Postmodernisme (Yogyakarta: Pustaka Pelajar, 1995), 90. 
kebangkitan sesuai dengan kebutuhan masa kini yang dulunya dibangun oleh para pendahulu sebagai jawaban atas kebutuhan masa mereka. ${ }^{3}$

Ada dua hal mendasar yang perlu diperhatikan, pertama, perlu dibangun kembali pemahaman tentang akidah, persepsi mengenainya dan pengakarannya pada jiwa masa kini. Di samping itu juga perlu peradaban yang mengakar pada masa lampau, namun berdiri di atas analisis psiko-sosial masyarakat modern. Kedua, tugas Ilmu Usuluddin adalah sebagai ideologi operasional gerakan sejarah. Hal ini dapat terjadi setelah masyarakat dimobilisasi melalui revolusi akidah. ${ }^{4}$

Pada sisi yang lain, agar teologi Islam mempunyai kajian yang lebih luas dan lebih relevan dengan konteks kekinian, orientasinya sebagai sebuah ilmu perlu diubah, teologi Islam harus dijadikan tidak lebih dari sebuah falsafah tentang teologi Islam. Hal ini setidaknya sebagaimana diistilahkan oleh Wolfson yang menyebut dalam judul bukunya dengan The Philosophy of Kalam. Hal mendasar yang dapat kita maknai dari fenomena ini, teologi Islam dikehendaki tidak lebih dari suatu bentuk falsafah atau gagasan pemikiran ketuhanan yang dibentuk oleh tantangan zamannya. Oleh karenanya, usaha untuk mengembangkan teologi Islam menjadi sesuatu yang mungkin. Orang menjadi tidak segan lagi mempertanyakan ulang dan meninjau kembali gagasan pemikiran yang telah dicetak para pemikir terdahulu yang notabene mempunyai tantangan berbeda sesuai dengan zaman yang melingkupinya pada saat itu. Oleh karena itu, apa yang oleh Rahman disebut atic reconstruction dalam teologi Islam akan dapat mengejawantah dalam pemikiran modern. ${ }^{5}$

Sudah momentnya manusia sebagai pusat kesadaran dalam menyelesaikan setiap problem yang melingkupinya. Untuk itu, peran aktif setiap komponen bangsa tidak terkecuali para teolog Islam harus mampu memberikan solusi terbaik dalam menyikapi problem umat kekinian.

${ }^{3}$ Lihat Machasin, Teologi Revolusiner Hasan Hanafi (t.tp., 1996), 6.

${ }^{4}$ Ibid.

${ }^{5}$ Muhammad In'am Esha, Teologi Islam, Isu-isu Kontemporer (Malang: UIN Malang Press, 2008), 9-10. 


\section{Problem Kekinian dan Solusinya}

Terdapat aneka macam persoalan umat kekinian khususnya di Indonesia yang seharusnya menjadi perhatian bagi para teolog Islam dalam pencarian solusi terbaik. Dalam konteks ini penulis membagi problem itu dalam beberapa bagian penting sebagaimana diuraikan dalam sub-sub bahasan di bawah ini.

\section{Problem Terkait Hubungan Islam dan Budaya Lokal}

Hubungan Islam dan budaya Lokal masih menyisakan prolem serius di kalangan umat. Di antara persoalan tersebut adalah masih ditemukannya klaim negatif terhadap budaya lokal yang dianggap sebagai bagian dari bentuk kemusyrikan yang diwariskan dari agama orang tua terdahulu, sehingga menurutnya ajaran-ajaran yang terkontaminasi dengan budaya lokal harus dihilangkan. Dari upaya tersebut muncul masalah baru; apakah Islam tidak menghargai budaya lokal? jika budaya tersebut dihapus apakah manusia tidak tercerabut dari akar budayanya? Ke mana harus berkiblat? Apakah negara yang menjadi kiblat sesuai dengan budaya lokal (Indonesia)?, mampukah umat Islam menjadikannya sebagai kiblat?, dan masih banyak pertanyaan yang muncul terkait hal tersebut.

Persoalan yang terkait hubungan agama dan budaya lokal pada titik tertentu akan berbahaya, sebab akan muncul klaim kebenaran di satu sisi dan klaim kafir di sisi lainnya. Term kafir akan mengulang sejarah kajian teologi Islam Klasik ketika Khawarij mengkafirkan seluruh umat Islam yang tidak sepaham dengannya. Dampak yang ditimbulkan adalah munculnya fenomena pembunuhan massal atas nama penyelamatan akidah sebagaimana yang telah terekam dalam sejarah kelam Khawarij.

Pada dasarnya, manusia menciptakan budaya dan lingkungan sosial mereka sebagai adaptasi terhadap lingkungan fisik dan biologisnya. Kebiasaan-kebiasaan, praktek, dan tradisi diwariskan dari generasi ke generasi. Pada gilirannya kelompok atau ras tersebut tidak menyadari dari mana asal warisan kebijaksanaan tersebut. Generasi berikutnya terkondisikan menerima "kebenaran" itu tentang nilai, pantangan, kehidupan, dan standar perilaku. Individu-individu cenderung menerima dan percaya apa yang dikatakan budaya mereka. Di saat itulah muncul apa 
yang disebut sebagai budaya lokal yang sering diistilahkan dengan "kearifan lokal" yang kemudian menjadi pegangan hidup bagi suatu komunitas tertentu. Kearifan lokal merupakan bagian dari konstruksi budaya. Dalam pandangan John Haba dalam Irwan Abdullah, kearifan lokal "mengacu pada berbagai kekayaan budaya yang tumbuh dan berkembang dalam sebuah masyarakat dikenal, dipercayai, dan diakui sebagai elemenelemen penting yang mampu mempertebal kohesi sosial di antara warga masyarakat". ${ }^{6}$

Dengan demikian, keberadaan agama tidak lepas dari pengaruh realitas di sekelilingnya. Seringkali praktek-praktek keagamaan pada suatu masyarakat dikembangkan dari doktrin ajaran agama dan kemudian disesuaikan dengan lingkungan budaya. Pertemuan antara doktrin agama dan realitas budaya terlihat sangat jelas dalam praktek ritual agama. Dalam Islam, misalnya saja perayaan Idul Fitri di Indonesia yang dirayakan dengan tradisi sungkeman (bersilaturahmi kepada yang lebih tua) adalah sebuah bukti dari keterpautan antara nilai agama dan kebudayaan. Pertautan antara agama dan realitas budaya dimungkinkan terjadi karena agama tidak berada dalam realitas yang vakum-selalu original. Mengingkari keterpautan agama dengan realitas budaya berarti mengingkari realitas agama sendiri yang selalu berhubungan dengan manusia, yang pasti dilingkari oleh budayanya. ${ }^{7}$

Kenyataan yang demikian itu juga memberikan arti bahwa perkembangan agama dalam sebuah masyarakat-baik dalam wacana dan praktek sosialnya-menunjukkan adanya unsur konstruksi manusia. Walaupun tentu pernyataan ini tidak berarti bahwa agama semata-mata ciptaan manusia, melainkan hubungan yang tidak bisa dielakkan antara konstruksi Tuhan seperti yang tercermin dalam Kitab-kitab Suci dan konstruksi manusia sebagai terjemahan dan interpretasi dari nilai-nilai suci agama yang direpresentasikan pada praktek ritual keagamaan. Pada saat manusia melakukan interpretasi terhadap ajaran

'Irwan Abdullah, dkk., Agama dan Kearifan Lokal dalam Tantangan Global (Yogyakarta: Sekolah Pascasarjana UGM dan Pustaka Pelajar, 2008), 7.

7Jamhari Ma'ruf, "Pendekatan Antropologi dalam Kajian Islam", bttp:/ / www.ditpertais.net; diakses tanggal 25 September 2012. 
agama, maka mereka dipengaruhi oleh lingkungan budaya (primordial) yang telah melekat di dalam dirinya. Hal ini dapat menjelaskan kenapa interpretasi terhadap ajaran agama berbeda dari satu masyarakat ke masyarakat lainnya. Kajian komparatif Islam di Indonesia dan Maroko yang dilakukan oleh Clifford Geertz misalnya, membuktikan adanya pengaruh budaya dalam memahami Islam. Di Indonesia Islam menjelma menjadi suatu agama yang sinkretik, sementara di Maroko Islam mempunyai sifat yang agresif dan penuh gairah. Perbedaan manifestasi agama itu menunjukkan betapa realitas agama sangat dipengaruhi oleh lingkungan budaya. ${ }^{8}$

Perdebatan dan perselisihan dalam masyarakat Islam sesungguhnya adalah perbedaan dalam masalah interpretasi, dan merupakan gambaran dari pencarian bentuk pengamalan agama yang sesuai dengan kontek budaya dan sosial. Misalnya dalam menilai persoalan-persoalan tentang hubungan politik dan agama yang dikaitkan dengan persoalan kekuasaan dan suksesi kepemimpinan, adalah persoalan keseharian manusia-dalam hal ini masalah interpretasi agama dan penggunaan simbol-simbol agama untuk kepentingan kehidupan manusia. Tentu saja peran dan makna agama akan beragam sesuai dengan keragaman masalah sosialnya.

Selama ini K.H. Abdurrahman Wahid (Gusdur) dikenal sebagai pelopor dalam mengintroduksir konsep Islam kultural di Indonesia. Menurut konsep ini, masyarakat muslim harus mampu mengakrabi budaya di sekitarnya, karena prinsip universal dalam ajaran Islam mengharuskan mereka untuk mengakomodir budaya partikular yang hidup di tempat tinggal mereka. Pandangan seperti ini dimaksudkan agar kehadiran Islam bisa membawa serta keramahan kepada lingkungannya. Gusdur tampaknya mengadopsi pendekatan kultur para mubalig awal (wali) Islam. Seperti diketahui bahwa para mubalig tersebut menanggalkan perangkat simbol eksklusif Islam (Arab) dan menggantinya dengan perangkat simbol lokal. Mereka mengintegrasikan ajaran Islam ke dalam simbol lokal, agar Islam dapat bersinergi dengan kultur Indonesia. Dengan akulturasi seperti itu, maka transformasi ajaran Islam ke alam pikiran

\section{Ibid.}


masyarakat Indonesia bisa berjalan sangat efektif. Masyarakat Muslim Indonesia akhirnya memang dikenal menjadi komunitas yang paling sedikit penyerapannya terhadap simbol eksklusif Arab (The least Arabisized Muslims). ${ }^{9}$

Sikap Gus Dur tersebut sangat berseberangan dengan pandangan kelompok Islam militan yang cenderung bersikap antagonistik terhadap budaya lain. Mereka hanya mengakui keabsahan produk budaya yang diperoleh melalui aktifitas internal masyarakat Muslim sendiri. Aktifitas itu pun baru bisa diterima menjadi bagian dari tradisi Islam yang "sah" setelah mendapatkan justifikasi tekstual dari dua sumber hukum Islam (al-Qur'an dan Sunnah) atau dari praktek kehidupan komunitas Muslim era ideal Islam (The Islamic era par-excellence). Pandangan eksklusif seperti ini kemudian membentuk sebuah model dialektika dikotomis antar Muslim (Self) dan non-Muslim (Other). Pandangan dikotomis tentu saja berimplikasi buruk terhadap sikap sosial mereka kepada kelompok agama lain. Mereka misalnya, selalu bertindak reaktif terhadap kebijakan pemerintahan Gus Dur, yang berkaitan dengan kepeduliannya terhadap komunitas agama lain. Gus Dur memang tidak pernah bergeming dengan sikap reaktif tersebut. Sebagai presiden pada saat itu, Gus Dur yang harus mengayomi semua warga negaranya tanpa melihat dominasi agamanya, justru semakin meningkatkan peran pendekatan Islam kultural, agar komunikasi dengan semua kelompok agama bisa berlangsung dengan baik. ${ }^{10}$

Dari uraian di atas, dapat dipahami bahwa masyarakat muslim harus mampu mengakrabi budaya di sekitarnya, karena prinsip universal ajaran Islam bersifat mengakomodir budaya partikular yang hidup di sekitarnya. Dengan mengakrabi budaya lokal tersebut (baca: kearifan lokal) akan membawa dampak positif bagi upaya perdamaian di Indonesia.

\section{Problem Terkait Hubungan Agama dan Negara}

Dalam konteks keindonesiaan, masyarakat Indonesia adalah masyarakat majemuk, baik dalam skop nasional maupun daerah.

${ }^{9}$ Thoha Hamim, dkk, Resolusi Konflik Islam di Indonesia (Yogyakarta: LKiS Pelangi Aksara, 2007), 3.

${ }^{10}$ Ibid. 
Kemajemukan itu sifatnya multi dimensional, ada yang ditimbulkan oleh perbedaan suku, tingkat sosial, pengelompokan organisasi politik, agama dan sebagainya. ${ }^{11}$

Menyikapi keragaman tersebut, negara harus pandai memposisikan dirinya. Dalam hal agama, negara harus hadir memberikan rasa keadilan untuk semua warga negara tanpa adanya diskriminasi karena pemihakannya pada agama tertentu. Hubungan agama dan negara sampai hari ini masih menyisakan berbagai problem; apakah agama menjadi wilayah yang harus diatur oleh negara atau agama adalah wilayah individu yang mana pemerintah/negara tidak boleh turut campur di dalamnya?, mampukah negara memberikan rasa keadilan dalam hal putusan khususnya masalah penodaan agama?, mampukah agama memberikan rasa aman bagi warganya dalam menjalankan agamanya?, apakah negara telah mensahkan seluruh agama di Indonesia? dan lain sebagainya.

Akhir-akhir ini telah terbentuk pencitraan buruk di tengahtengah masyarakat akan kekerasan yang dilakukan oleh agama ketika berkuasa, agama terkadang hanya sebagai alat legitimasi kekuasaan negara untuk kepentingan golongan tertentu. Gagalnya negara dalam menghalau isu-isu yang bernuasa SARA (Suku, Agama, Ras, dan Antar Golongan)telah menelan korban jiwa yang tidak terhitung jumlahnya. Azyumardi Azra ${ }^{12}$ menyebut beberapa kerusuhan massal yang pernah terjadi di Indonesia, di antaranya: Kerusuhan Timor Timur yang merupakan bagian yang tidak terpisahkan dari perjuangan mereka untuk memisahkan diri dari Indonesia dan akhirnya menuju kemerdekaan; Kerusuhan Aceh akibat pemerintah pusat (Jakarta) menerapkan kebijakan-kebijakan yang tidak dapat diterima oleh masyarakat Aceh. Pada tanggal 4 Desember 1977, Hasan Tiro memproklamirkan berdirinya "Aceh Merdeka". Sejak saat itu, sejarah Aceh berubah menjadi sasaran kekerasan (penindasan) militer dan ketidakadilan politik maupun ekonomi;

${ }^{11}$ M. Atho Mudzhar, Pendekatan Studi Islam dalam Teori dan Praktek (Yogyakarta: Pustaka Pelajar, 2001), 127.

${ }^{12}$ Azyumardi Azra, Kerusuban-kerusuhan Massal yang Terjadi di Indonesia Baru-baru Ini: Kemunduran Nasionalisme dan Kemunculan Separatisme -Konflike Komunal di Indonesia Saat Ini (Jakarta: INIS, 2003), 61-75. 
Kerusuhan Ambon merupakan konflik dan kekerasan-kekerasan keagamaan di Indonesia yang tidak hanya mengakibatkan pembunuhan terhadap sejumlah besar orang (dari kalangan Muslim maupun Kristen), tetapi sekaligus juga pembakaran masjid-masjid, gereja-gereja, rumah-rumah, pasar serta bangunan dan fasilitas umum lainnya. Menurut sebuah laporan (pada tanggal 27 November 1999), kekerasan yang terjadi 11 bulan sebelumnya mengakibatkan 693 orang meninggal, dan hampir 2000 orang terluka serta perusakan terhadap bangunan yang tidak terhitung jumlahnya; Kerusuhan Kalimantan Barat cukup diwarnai oleh konflik etnik yang mengakar antara penduduk asli Dayak (yang kemudian didukung masyarakat Melayu) dan masyarakat pendatang Madura. Dilaporkan bahwa lebih dari 1.720 orang terbunuh di Sanggau Ledo (Sambas). Konflik lainnya yang menunjukkan ketidakprofesionalnya negara adalah kasus penyerangan Sunni terhadap Syiah di Sampang Madura yang juga menelan korban jiwa.

Tentu saja gambaran konflik di atas, hanya sebagian kecil dari konflik yang pernah terjadi di Indonesia yang membutuhkan perhatian serius negara tidak terkecuali para teolog untuk menemukan solusi terbaik dalam menyelesaikan permasalahan tersebut.

Kasus keberpihakan negara terhadap agama atau paham tertentu telah terjadi sejak periode klasik. Mu'tazilah yang bercorak rasional pun terperangkap pada pemaksaan ideologi ketika ia menjadi mazhab negara. Mereka memaksakan ideologi agar para pejabat negara disumpah untuk mengakui bahwa alQur'an adalah makhluk. Tidak hanya pejabat negara, para fuqaha pun dipaksa untuk mengakuinya. Walhasil bukan pengakuan yang muncul, namun penindasan yang berujung pada penghapusan paham Mu'tazilah sebagai mazhab negara. Selain itu, dalam sejarah Syiah dan Sunni, keduanya saling mendominasi ketika salah satu dari mereka menjadi mazhab negara. Tentu kita tidak ingin hal tersebut terjadi lagi di era kekinian. Untuk itu, perlu sosialiasi pemahaman yang baik dalam menyikapi hubungan agama dan negara.

Khusus konflik antar umat beragama, jika kita kembali kepada ajaran agama bahwa ajaran kebaikan, cinta kasih dan 
kerukunan, secara normatif-doktriner selalu diajarkan. Tetapi, kenyataan sosiologis seringkali memperlihatkan sebaliknya, agama justru menjadi ajang konflik yang tak kunjung reda. ${ }^{13}$ Menurut Arthur J. D' Adamo, Religion's way of knowing dalam Samiang Katu, sebagai akar dari konflik-konflik antar umat beragama, mereka yang tidak kritis terhadap ajaran agamanya berkeyakinan bahwa agamanya memiliki ajaran: 1) Bersifat konsisten dan berisi kebenaran-kebenaran yang tanpa kesalahan sama sekali; 2) Bersifat lengkap dan final - dan karena itu memang tidak diperlukan kebenaran dari agama lain; 3) Kebenaran agamanya sendiri dianggap merupakan satu-satunya jalan keselamatan, pencerahan atau pembebasan; dan 4) Seluruh kebenaran itu diyakini orginal dari Tuhan, tidak ada konstruksi manusia. ${ }^{14}$

Keempat akar konflik antar agama menurut Budhy Munawar Rachman, menjadikan agama sebagai sumber ketidakharmonisan hubungan antar umat beragama. Mereka terperangkap pada klaim-klaim hanya agamanyalah yang benar, sementara yang lain salah. Kondisi riil seperti ini, jika dipandang dari sudut teologis dan epistemologis menjadi penyebab munculnya kebingungan di antara umat beragama, ketika menyaksikan bahwa di sekitar mereka, penganut agama lain juga berkeyakinan bahwa hanya agamanyalah yang paling benar, sementara yang lainnya salah. Akibat selanjutnya, agama yang satu menjadi ancaman bagi agama yang lain. Dalam kondisi seperti ini, seringkali persoalannya semakin rumit dan kompleks, bilamana persoalan politik ikut serta di dalamnya. Logikanya pun menjadi : "siapa kebetulan berkuasa, dialah yang akan mendominasi yang lain". ${ }^{15}$ Moch Qasim Mathar menyatakan bahwa klaim kebenaran pada

13Zulkarnain, dkk., Model Landasan Sosial antara Umat Beragama dalam Memelihara Ketahanan dan Ketertiban Masyarakat Miskin pada Daerah Terpencil dan Terisolasi di Pulau Enggano (Jakarta: Direktorat Perguruan Tinggi Agama Islam Ditjen Kelembagaan Agama Islam Departemen Agama, 2004), 5.

${ }^{14}$ Samiang Katu, Paradigma Baru: Hubungan Antara Islam dan Kristen (Pilar Utama Memperkokoh Negara Kesatuan Republik Indonesia (Orasi Pengukuhan Guru Besar Bidang Perbandingan Agama, IAIN Alauddin Makassar, 2003), 16.

${ }^{15}$ Budhy Munawar Rachman, Islam Pluralis Wacana Kesetaraan Kaum Beriman (Jakarta: Paramadina, 2001), xi. 
agama dan keyakinan sendiri - dan kebatilan (kesesatan) di pihak umat lain - sudah menjadi bagian dari perjalanan sejarah umatumat dari agama-agama yang berbeda. Sampai hari ini, di kalangan umat Islam, klaim tersebut masih dijumpai. Sejarah pemikiran Islam yang meliputi teologi, filsafat, dan mistisisme (tasawuf) telah mencatat kelompok-kelompok teologi tertentu mengkafirkan kelompok teologi Islam lainnya yang berbeda. Pemikiran-pemikiran filsafat dan tasawuf pun, di antaranya mengalami pengkafiran serupa. Tentu tuduhan pengkafiran itu menjadi amat serius kalau yang dituduh sampai dihukum mati. ${ }^{16}$

Kenyataan seperti inilah telah direkam dalam blue print bukubuku sejarah konflik antar agama. Dengan demikian, jelaslah bahwa sumber-sumber konflik antar umat beragama, berasal dari cara pemahaman agama yang sifatnya parsial dan tidak komprehensif. Di samping itu, keyakinan penganut agama lain di luar dirinya, dinilai berdasarkan konsep keyakinannya.

Berdasarkan paparan di atas, dalam konflik baik yang sarat dengan muatan "nasionalisme lokal" atau sentimen separatisme maupun yang bernuansa SARA, terdapat konflik yang disebabkan upaya penyeragaman agama oleh negara terhadap kelompok minoritas, yang kemudian memancing kelompokkelompok itu bertindak melawan negara atau kelompok lain.

\section{Islam dan Problem Radikalisme Agama}

Radikalisme agama bukanlah merupakan fenomena yang berkembang hanya pada komunitas tertentu. Keberadaan radikalisme sudah berkembang dalam bentuk yang bercorak trans-nasional karena bisa dijumpai hampir di setiap wilayah negara di muka bumi ini. Keberadaan radikalisme juga bercorak trans-religion karena dialami oleh semua agama. Fenomena ini telah berlangsung lama dan tersebar pada semua agama yang ada di muka bumi ini. ${ }^{17}$

${ }^{16}$ Moch Qasim Mathar, Kimiawi Pemikiran Islam - Arus Utama Islam di Masa Depan (Orasi Pengukuhan Guru Besar Ilmu Filsafat dan Pemikiran Modern dalam Islam, Fakultas Ushuluddin dan Filsafat UIN Alauddin Makassar, 2007), 3.

${ }^{17}$ Nuhrison M. Nuh, Peranan Pesantren dalam Mengembangkan Budaya Damai (Jakarta: Badan Litbang dan Diklat Kementerian Agama, 2010), 1. 
Terminologi tentang "radikalisme" cukup beragam. Di antaranya, kata "radikal" mengacu kepada keadaan, orang, atau gerakan tertentu yang menginginkan perubahan sosial dan politik secara cepat dan menyeluruh, dan tidak jarang dilakukan dengan menggunakan cara-cara tanpa kompromi dan bahkan kekerasan, bukan dengan cara-cara damai. ${ }^{18}$ Dengan demikian radikalisme keagamaan berhubungan dengan cara memperjuangkan keyakinan keagamaan yang dianutnya dengan tanpa kompromi dan bila perlu dilakukan dengan cara anarkisme dan kekerasan.

Adapun beberapa faktor yang memunculkan radikalisme dalam bidang agama, antara lain: a) Pemahaman yang keliru, atau sempit tentang ajaran agama yang dianutnya, b) Ketidakadilan sosial, c) Kemiskinan, d) Dendam politik dengan menjadikan ajaran agama sebagai satu motivasi untuk membenarkan tindakannya, dan e) Kesenjangan sosial atau iri hati atas keberhasilan orang lain. ${ }^{19}$ Faktor-faktor itu harus disikapi secara arif dengan mencari solusi terbaik tanpa harus mengorbankan pihak lain. Sebab radikalisme agama pada tahap selanjutnya akan melahirkan terorisme sebagaimana pendapat Hasyim Muzadi, "Terorisme berkembang seiring dengan masifnya perkembangan faham radikalisme agama. Maraknya gerakan radikalisme agama menjadi ladang subur bagi terorisme."20

Islam adalah agama damai, agama penuh toleransi, agama yang menjunjung tinggi nilai kemanusiaan serta menentang pengrusakan atau pembunuhan, baik dilakukan secara masif atau terhadap individu. Islam sangat menghargai dan menghormati hak asasi manusia baik itu agama, nyawa, harta, nasab, dan keturunan. Allah swt. berfirman dalam Qs. al-Mā’idah (5):32:

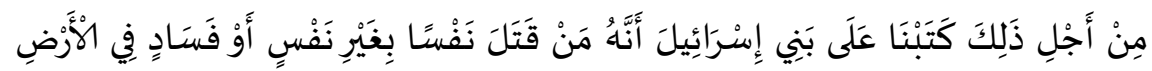

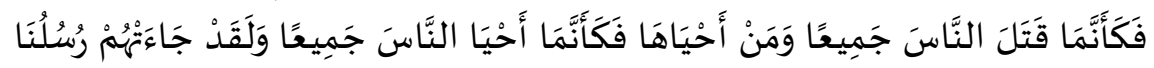

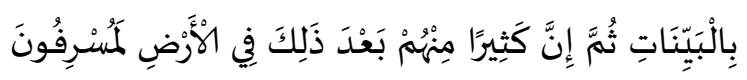

18Ibid., 2.

${ }^{19}$ Ibid.

${ }^{20}$ Hasyim Muzadi, "Terorisme Subur Akibat Radikalisme Agama"http:/ / www.nu.com; diakses tanggal 25 September 2012. 
Artinya: Oleh Karena itu kami tetapkan (suatu hukum) bagi Bani Israil, bahwa: barangsiapa yang membunuh seorang manusia, bukan karena orang itu (membunuh) orang lain, atau bukan karena membuat kerusakan di muka bumi, Maka seakan-akan dia telah membunuh manusia seluruhnya. Dan barangsiapa yang memelihara kehidupan seorang manusia, maka seolah-olah dia telah memelihara kehidupan manusia semuanya. Dan sesungguhnya Telah datang kepada mereka rasul-rasul kami dengan (membawa) keteranganketerangan yang jelas, kemudian banyak di antara mereka sesudah itu sungguh-sungguh melampaui batas dalam berbuat kerusakan di muka bumi.

Tentu saja hukum ini bukanlah mengenai Bani Israil saja, tetapi juga mengenai manusia seluruhnya. Allah memandang bahwa membunuh seseorang itu adalah sebagai membunuh manusia seluruhnya, karena setiap orang itu adalah anggota masyarakat dan karena membunuh seseorang berarti juga membunuh keturunannya.

Menghalalkan segala cara untuk mencapai tujuan bukan cara yang dicontohkan oleh Islam. Jika terjadi perang, Islam pun telah memberikan kaidah-kaidah yang harus ditaati seperti; tidak boleh membunuh orang yang telah menyerah, tidak boleh membunuh wanita, orang tua, anak kecil, tidak boleh merusak tanaman, dan tempat ibadah. Tawanan perang dalam Islam juga dijaga dan diperlakukan secara manusiawi.

Dengan demikian, Islam sangat anti kekerasan, siapapun pelakunya, apapun motifnya, Islam sangat menentang hal tersebut. Untuk itu, upaya sosialisasi Islam sebagai agama damai harus didengungkan tidak terkecuali oleh para teolog Islam kekinian. Bahkan seharusnya, para teolog mampu menjelaskan manfaat dan mudarat setiap problem umat serta solusinya.

\section{Islam dan Problem Kemiskinan}

Problem kemiskinan di Indonesia telah menjadi suguhan pemberitaan media massa setiap harinya, bila terjadi pembiaran maka kemiskinan akan melahirkan problem sosial yang berkepanjangan. Dalam kajian teologi, kemiskinan dihubungkan dengan faham Jabariyah yang meyakini bahwa semuanya telah ditentukan oleh Allah, manusia miskin adalah kehendak Allah. Apakah betul kemiskinan adalah takdir Allah?, apakah manusia tidak memiliki daya efektif untuk merubah nasibnya?, adilkah 
Tuhan ketika suatu negara lebih miskin di banding negara lain?. Dan berbagai pertanyaan yang muncul terkait masalah kemiskinan tersebut. Jika para teolog Islam klasik selalu berbicara seputar menyalahkan Tuhan atau manusia, maka teolog Islam kekinian seharusnya lebih jauh menyikapi persoalan tersebut secara arif dan bijaksana.

Di antara penyebab kemiskinan di Indonesia adalah beban hidup yang berat, tingkat pendapatan yang rendah, ketersediaan lapangan kerja yang tidak memadai, SDM atau keahlian yang rendah, kurangnya pemanfaatan sumber daya alam (ekonomi nasional), tingkat pengangguran yang tinggi, keterbatasan dalam hal memanfaatkan sumber informasi dan teknologi, ketidakmerataan kesejahteraan hidup, dan ada juga yang disebabkan oleh kemiskinan struktural.

Khusus untuk kemiskinan struktural, hal tersebut merupakan sisi eksternal dari si miskin. Ia berkaitan dengan kegagalan sistem politik, institusi pemerintah, struktur elit dan birokrasi kekuasaan, serta berbagai kebijakan yang "pro-rakyat" (people-oriented development). Di satu sisi Pemerintah berusaha memerangi kemiskinan (the poverty alleviation) karena faktor struktural, kultural, dan natural, tetapi kemudian terjebak dalam perangkap kemiskinan itu sendiri (the poverty traps). Dalam arti ketika Pemerintah berusaha menjawab pertanyaan kemiskinan ekonomi dan persoalan keterbelakangan sosial, ternyata di dalam jawaban masih banyak menyisakan pertanyaan. Inilah yang dikenal dengan istilah "antagonistic developmentalism". ${ }^{21}$ Untuk itu, pemerintah harus jeli untuk membuat kebijakan yang pro rakyat.

Salah satu upaya yang dapat dilakukan dalam memecahkan persoalan kemiskinan di Indonesia adalah pemberdayaan ekonomi umat. Pengembangan ekonomi umat di Indonesia memang merupakan persoalan besar yang dihadapi dan harus diupayakan pemecahannya oleh umat itu sendiri. Dalam rangka mencapai sasaran pengembangan ekonomi umat itu, diperlukan perhatian khusus terhadap kelompok usahawan umat, terutama yang bergerak dalam sektor usaha berskala kecil. Dengan

21Syamsul Bahrum, "Kemiskinan Struktural dari Perspektif Teoritis" http:/ / www.haluankepri.com; diakses tanggal 24 September 2012. 
perkataan lain, bahwa pengembangan dan pembinaan usahawan umat yang mengelola usaha berskala kecil, bisa dikatakan sebagai bagian penting dalam usaha-usaha pengembangan ekonomi secara keseluruhan. ${ }^{22}$

Komunikasi, koordinasi, dan konsultasi antara masyarat usahawan umat dan instansi pemerintah perlu ditingkatkan, supaya terjalin suasana "saling pengertian" yang memungkinkan terjadinya titik temu, terutama dalam rangka mencari solusi terbaik terhadap problematika yang dihadapi para usahawan umat itu sendiri. Dengan adanya "saling pengertian" tersebut, maka dapat diharapkan adanya "kebijaksanaan ekonomi makro", yang penerapannya berorientasi dan menguntungkan bagi aktivitas bisnis kelompok usahawan umat. Dalam konteks inilah diperlukan adanya suatu business network yang berwawasan keislaman, yang dikendalikan oleh bank yang beroperasi berdasarkan syariat Islam. ${ }^{23}$

Untuk memberikan arah yang lebih baik terhadap kegiatan pengembangan ekonomi umat di Indonesia, jelas diperlukan adanya karya-karya akademis (tidak terkecuali teolog Islam), dan hasil-hasil penelitian, yang secara khusus membahas segala sesuatu yang berkenaan dengan masalah ekonomi Islam secara khusus, baik pada aspek macro economic maupun pada aspek micro ekonomic. Ini berarti, usaha-usaha pengembangan kegiatan studi ekonomi, bukan saja perlu dilanjutkan tetapi juga perlu semakin dimasyarakatkan. Sehingga kehidupan ekonomi umat bisa dijalankan dengan cara-cara yang lebih mengena dan lebih sesuai dengan ajaran Islam.

Di samping itu, perlu keseriusan umat untuk mengelola dan memanfaatkan zakat sebagai salah satu metode dalam menyelesaikan problem kemiskinan di Indonesia. Pada dasarnya, jika zakat dikelola secara profesional maka angka kemiskinan dapat ditekan setiap tahunnya. Hanya saja, tingkat kepercayaan masyarakat terhadap pengelolaan zakat masih rendah diakibatkan banyaknya penyelewengan dan tidak adanya transparansi dalam pendistribusian zakat. Ke depan, para teolog

${ }^{22}$ Adi Sasono, Solusi Islam atas Problematika Umat-Ekonomi, Pendidikan dan Dakwah (Jakarta: Gema Insani, 1998), 81.

${ }^{23}$ Ibid. 
Islam perlu mensosialisasikan metode pengelolaan zakat yang sesuai dengan ajaran Islam sehingga masyarakat tidak lagi menyalurkan zakatnya sendiri-sendiri.

\section{Islam dan Problem Korupsi}

Korupsi merupakan salah satu problem umat kekinian. Indonesia yang mayoritas beragama Islam tidak menjadikan negara ini bebas dari korupsi. Oknum-oknum koruptor pun tidak jarang beragama Islam dan beberapa kali naik haji. Sangat ironis memang, masyarakat muslimnya justru terjerumus pada perilaku yang justru menghancurkan reputasi pribadi dan negerinya sendiri.

Muncul pemisahan antara urusan duniawi dan akhirat. Ibadah tidak berimplikasi pada aktivitas keseharian manusia. Jika kita melirik ke kajian teologi Islam klasik, fenomena yang sama kita temukan pada kelompok Murji'ah yang lebih menekankan pada iman, di mana perbuatan tidak memengaruhi iman seseorang. Mereka tidak mementingkan akhlak sebab dalam keyakinannya, selama seseorang beriman pasti masuk Surga meskipun dia melakukan dosa besar. Boleh jadi para koruptor hari ini adalah jelmaan atau neomurji'ah. Persoalan korupsi di Indonesia telah mendarah daging, reformasi yang didengungkan mampu membawa perubahan besar tidak mampu berbuat apaapa dihadapan penguasa yang korup. Satu persatu pemimpin bangsa ini pun tersangkut kasus korupsi, tidak jauh berbeda dengan Orde Baru. Problem baru muncul, karena korupsi masyarakat dimiskinkan oleh sistem negara yang korup, APBN yang seharusnya mensejahterakan rakyat justru dinikmati oleh segelintir orang, masyarakat pun harus hidup dalam garis kemiskinan. Bila kesenjangan antara si kaya dan si miskin sudah sedemikian menganga, maka korupsi makin melebarkan kesenjangan itu karena uang terdistribusi secara tidak sehat atau dengan kata lain tidak mengikuti kaidah-kaidah ekonomi sebagaimana mestinya. Koruptor semakin kaya, yang miskin semakin miskin. Akibat lainnya, karena uang seolah mudah diperoleh, sikap konsumtif menjadi semakin merangsang, tidak ada dorongan kepada pola produktif, akhirnya timbul inefisiensi dalam pemanfaatan sumber daya ekonomi yang telah tersedia. 
Di samping itu, jika si miskin mencuri karena lapar maka hakim dengan cepat memutuskan hukumannya, lain halnya dengan koruptor yang layaknya pahlawan disorot oleh media dan dengan pengawalan berlapis masuk ke ruang Komisi Pemberantasan Korupsi (KPK). Tidak sedikit kasus korupsi yang hanya jalan di tempat atau dibebaskan karena alasan tidak cukup bukti. Bahkan baru-baru ini, upaya melemahkan KPK dengan mempereteli kewenangan yang dimilikinya merupakan bentuk ketidakberdayaan hukum di hadapan penguasa yang korup.

Tidak satupun agama di dunia ini yang mengajarkan tentang korupsi. Islam adalah bagian dari sistem yang raḅatan li al'álamin yang teruji di setiap zaman. Namun, sayang perilaku mental buruk manusia Islam yang tidak berlandaskan asas Islam itu sendiri yang akhirnya menjerumuskan manusianya ke ambang kemerosotan moral dan kehinaan melalui tindak pidana korupsi. Dalam hal korupsi Allah telah mengingatkan sebagaimana yang termaktub dalam firman-Nya,

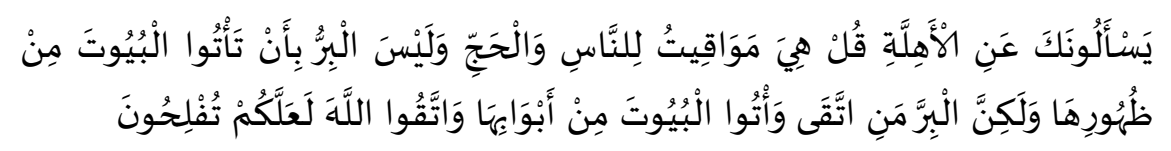

Artinya: "Dan janganlah sebahagian kamu memakan harta sebahagian yang lain di antara kamu dengan jalan yang bathil dan (janganlah) kamu membawa (urusan) harta itu kepada hakim, supaya kamu dapat memakan sebahagian daripada harta benda orang lain itu dengan (jalan berbuat) dosa, padahal kamu mengetahui." 24

Setiap manusia harus menyadari bahwa perilaku korupsi selain menyengsarakan orang lain juga akan menyengsarakan keluarganya. Bila dia dapat lolos dari hukum dunia (KPK), maka hukum Tuhan akan menanti. Untuk itu, sosialisasi tentang ajaran Islam yang anti korupsi harus senantiasa dilakukan sejak dini pada generasi muda, baik melalui pendidikan formal maupun non formal. Sudah waktunya pendidikan anti korupsi masuk dalam kurikulum SD sampai Perguruan Tinggi, bila negara ini ingin melakukan perubahan. Peran negarawan dan agamawan pun sangat dibutuhkan dalam mensosialisasikannya. Agamawan

${ }^{24}$ Qs. al-Baqarah (2):188. 
di setiap ceramahnya, tidak hanya berbicara tentang Surga dan Neraka tetapi lebih jauh menjelaskan dampak negatif perilaku korupsi di dunia, menanamkan pentingnya tanggung jawab dan profesionalisme dalam bekerja, dan yang lebih mendasar adalah merealisasikan keyakinan tersebut sejak dini yang dimulai dari diri sendiri, keluarga, lingkungan, berbangsa dan bernegara.

\section{Islam dan Problem Lingkungan}

Berbagai macam problem yang muncul terkait lingkungan sekarang ini, seperti meningkatnya gas rumah kaca yang berdampak pada meningkatnya pemanasan global (global warming), berakibat kepada meningkatnya suhu permukaan bumi yang memengaruhi perubahan iklim yang sangat ekstrim di bumi. Perubahan iklim yang ekstrim tersebut mengakibatkan terganggunya hutan, pertanian, perikanan dan ekosistem lainnya. Pemanasan global juga mengakibatkan mencairnya gunung es di kutub yang dapat menimbulkan naiknya permukaan air laut, dan akhirnya berdampak buruk pada negara kepulauan (tenggelam dan hilang). Problem lainnya adalah Krisis air (pencemaran air) dan krisis air bersih, banjir bandang, kekeringan yang panjang, kebakaran hutan, polusi udara, hujan, dan tanah longsor.

Problem lingkungan tersebut seyogyanya menggugah pemahaman keberislaman kita untuk meninjau kembali makna khalifah (aktif memakmurkan bumi). Khalifah tidak hanya bermakna pemimpin di bumi yang bebas mengeksploitasi alam tetapi khalifah bermakna memahami tugas-tugas manusia di bumi yakni memakmurkan alam itu sendiri.

Perspektif teologi tentang alam semesta memberikan peluang untuk mengkaji ulang posisi manusia dan tanggung jawab etisnya dalam relasi kesemestaan. Ia yang nantinya akan membongkar keyakinan bahwa manusia dan alam adalah dua "dunia" yang berbeda, yaitu manusia sebagai "pusat" (core) dan alam sebagai hal yang subordinat alias "yang lain" (the others). Pemahaman biner ini tidak bisa dijadikan alat justifikasi bahwa umat manusia sebagai objek yang bisa seenaknya mengeksploitasi alam. ${ }^{25}$

${ }^{25}$ Esha, Teologi Islam..., 26. 
Dengan pembumian teologi lingkungan, diharapkan kita akan sadar bahwa semua ciptaan Tuhan (manusia, alam, hewan) mempunyai hak untuk bereksistensi. Tidak ada satu pun mahluk hidup yang berhak menguasai sesamanya, selain Tuhan. Dalam Islam misalnya, Tuhan adalah penguasa tunggal yang mutlak dan tidak tergugat atas langit dan bumi (Qs. al-Baqarah [2]:107). Karena itu, ketika manusia mulai mengeksploitasi alam secara rakus, saat itu pula sebenarnya manusia telah berusaha "merampas" eksistensi dan kehidupan alam semesta. Dengan kata lain, manusia telah berusaha "menggugat" dan "merampas" hak dan kekuasaan Tuhan. Segala bentuk eksploitasi terhadap lingkungan adalah tindakan tidak bermoral yang harus dihindari karena unsur ketauhidan dan tanggung jawab moral kita sebagai khalifah di muka bumi. Sehingga visi dan misi teologi kita harus sampai pada aspek penyelamatan yang bersifat universal, keselamatan yang menjangkau seluruh aspek tidak saja aspek kedisanaan, tetapi juga aspek kedisinian. Tidak hanya berdimensi akhirat, tetapi juga di dunia yang kita tempati saat ini. ${ }^{26}$

Proses penyadaran harus senantiasa dilakukan oleh seluruh komponen bangsa ini sesuai dengan kapasitas yang dimiliki. Tanpa adanya upaya tersebut, ajaran agamapun tak mampu membawa perubahan pada perbaikan bangsa Indonesia. Upaya tersebut juga harus dilakukan secara berkesinambungan dan terus menerus.

\section{Catatan Akhir}

Ruh kajian teologi Islam Klasik dalam menanamkan pemahaman agama harus tetap dipertahankan guna membangun jiwa manusia dan peradabannya, namun kajiannya berdiri di atas psikososial masyarakat modern dan mampu menjadi solusi bagi problem-problem yang muncul. Untuk itu, reorientasi kajian teologi Islam harus mampu membenahi problem tersebut.

Tanggung jawab para teolog tidak lagi berkutat pada persoalan "membela Tuhan" tetapi masuk pada ranah yang lebih jauh, seperti menyelesaikan problem agama dan budaya lokal, problem hubungan agama dan negara, Islam dan problem

${ }^{26}$ Ibid. 
radikalisme, kemiskinan, korupsi, lingkungan hidup dan lainnya. Problem-problem tersebut merupakan problem mendasar yang jika tidak disikapi secara arif dan bijaksana akan melahirkan problem baru yang lebih besar dan merugikan umat. Untuk itu, peran seluruh komponen bangsa sangat dibutuhkan dalam menyelesaikan problem tersebut tidak terkecuali para teolog Islam. Dengan reorientasi arah kajian teologi Islam yang membumi akan mampu menjadikan kajian ini menarik dan menjadi rujukan umat dalam menyelesaikan problemnya. Wa alLäh a lam bi al-sawāb.

\section{Daftar Pustaka}

Abdulllah, Amin. 1995. Falsafah Teologi Islam di Era Postmodernisme. Yogyakarta: Pustaka Pelajar.

Abdullah, Irwan. dkk. 2008. Agama dan Kearifan Lokal dalam Tantangan Global. Yogyakarta: Sekolah Pascasarjana UGM dan Pustaka Pelajar.

Azra, Azyumardi. 2003. Kerusuban-kerusuban Massal yang Terjadi di Indonesia Baru-baru Ini: Kemunduran Nasionalisme dan Kemunculan Separatisme -Konflik Komunal di Indonesia Saat Ini. Jakarta: INIS.

Bahrum, Syamsul. "Kemiskinan Struktural dari Perspektif Teoritis" http://www.haluankepri.com; diakses tanggal 24 September 2012.

Hamim, Thoha. dkk. 2007. Resolusi Konflik Islam di Indonesia. Yogyakarta: LKiS Pelangi Aksara.

Esha, Muhammad In'am. 2008. Teologi Islam, Isu-isu Kontemporer. Malang: UIN Malang Press.

Jahja, Zurkani. 1996. Teologi al-Ghazali -Pendekatan Metodologi. Yogyakarta: Pustaka Pelajar.

Katu, Samiang. 2003. Paradigma Baru: Hubungan Antara Islam dan Kristen -Pilar Utama Memperkokoh Negara Kesatuan Republike Indonesia. Orasi Pengukuhan Guru Besar Bidang Perbandingan Agama, IAIN Alauddin Makassar.

Machasin. 1996. Teologi Revolusioner Hasan Hanafi. t.tp.

Ma'ruf, Jamhari "Pendekatan Antropologi dalam Kajian Islam", http:/ / www.ditpertais.net; diakses tanggal 25 September 2012. 
Mathar, Moch Qasim. Kimiawi Pemikiran Islam - Arus Utama Islam di Masa Depan. Orasi Pengukuhan Guru Besar Ilmu Filsafat dan Pemikiran Modern dalam Islam, Fakultas Usuluddin dan Filsafat UIN Alauddin Makassar, 2007.

Mudzhar, M. Atho. 2001. Pendekatan Studi Islam dalam Teori dan Praktek. Yogyakarta: Pustaka Pelajar.

Nuhrison, M. Nuh. 2010. Peranan Pesantren dalam Mengembangkan Budaya Damai. Jakarta: Badan Litbang dan Diklat Kementerian Agama.

Muzadi, Hasyim. "Terorisme Subur Akibat Radikalisme Agama" bttp:/ / www.nu.com, diakses tanggal 25 September 2012.

Rachman, Budhy Munawar. 2001. Islam Pluralis Wacana Kesetaraan Kaum Beriman. Jakarta: Paramadina.

Sasono, Adi. 1998. Solusi Islam atas Problematika Umat-Ekonomi, Pendidikan dan Dakwah. Jakarta: Gema Insani.

Zulkarnain, dkk. 2004. Model Landasan Sosial antara Umat Beragama dalam Memelihara Ketahanan dan Ketertiban Masyarakat Miskin pada Daerah Terpencil dan Terisolasi di Pulau Enggano. Jakarta: Direktorat Perguruan Tinggi Agama Islam Ditjen Kelembagaan Agama Islam Departemen Agama. 